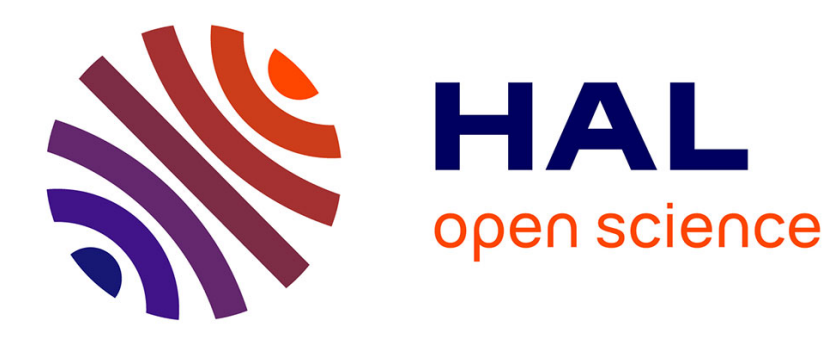

\title{
Superconductivity of disordered palladium
}

B. Stritzker

\section{To cite this version:}

B. Stritzker. Superconductivity of disordered palladium. Journal de Physique Lettres, 1978, 39 (21), pp.397-398. 10.1051/jphyslet:019780039021039700 . jpa-00231526

\section{HAL Id: jpa-00231526 https://hal.science/jpa-00231526}

Submitted on 1 Jan 1978

HAL is a multi-disciplinary open access archive for the deposit and dissemination of scientific research documents, whether they are published or not. The documents may come from teaching and research institutions in France or abroad, or from public or private research centers.
L'archive ouverte pluridisciplinaire HAL, est destinée au dépôt et à la diffusion de documents scientifiques de niveau recherche, publiés ou non, émanant des établissements d'enseignement et de recherche français ou étrangers, des laboratoires publics ou privés. 


\title{
SUPERCONDUCTIVITY OF DISORDERED PALLADIUM (*)
}

\author{
B. STRITZKER \\ Institut für Festkörperforschung, KFA Jülich, D-5170 Jülich, Germany
}

(Reçu le 23 août 1978, accepté le 15 septembre 1978)

\begin{abstract}
Résumé. - On a observé la supraconductivité jusqu'à 3,2 $\mathrm{K}$ dans des films de palladium après irradiation à basses températures avec des ions $\mathrm{He}^{+}$.
\end{abstract}

Abstract. - Superconductivity up to 3.2. $\mathrm{K}$ has been found in $\mathrm{Pd}$ films after $\mathrm{He}^{+}$irradiation at low temperatures.

Very pure Pd films have been condensed onto substrates either at $4 \mathrm{~K}, 77 \mathrm{~K}$ or $300 \mathrm{~K}$ using various evaporation sources and methods. The as-condensed Pd films do not become superconducting above $0.08 \mathrm{~K}$. Irradiation of these films with $130 \mathrm{keV} \mathrm{He}^{+}$ions at $4.2 \mathrm{~K}$ leads in all cases to superconductivity. The film thicknesses (200-400 $\AA$ ) are chosen so that the $\mathrm{He}^{+}$-ions pass through the $\mathrm{Pd}$. The maximum observed transition temperature, $T_{\text {cmax }}$, amounts to $3.2 \mathrm{~K}$ for very small ion beam densities. $T_{\text {cmax }}$ decreases with increasing density of the ion beam. $T_{\mathrm{c}}$ does not depend significantly either on the substrate $\left(\mathrm{Al}_{2} \mathrm{O}_{3}\right.$, $\mathrm{SiO}_{2}$ ) or the evaporation conditions. Pd films evaporated with a rate of $80 \AA / \mathrm{s}$ by means of an electron-gun at $2 \times 10^{-10}$ torr before and $5 \times 10^{-9}$ torr during evaporation become superconducting after irradiation the $T_{\mathrm{c}}$ values are comparable with films evaporated at $3 \AA / \mathrm{s}$ and $10^{-7}$ torr.

Figure 1 shows the residual resistivity $\rho_{n}$ of a Pd film condensed at $4.2 \mathrm{~K}$ versus the dose of $\mathrm{He}^{+}$-ions. After a steep decrease $\rho_{n}$ saturates and superconductivity occurs. The decrease of $\rho_{n}$ indicates that defects introduced during the quenched condensation partially anneal during irradiation. Annealing of this sample at $300 \mathrm{~K}$ results in a further decrease of $\rho_{n}$. Another $4.2 \mathrm{~K}$ irradiation of this annealed sample enlarges $\rho_{n}$ again. $\rho_{n}$ saturates at nearly the same value as before and the Pd film becomes superconducting at similar $T_{\mathrm{c}}$ values. This behaviour of the resistance indicates that superconductivity occurs in a phase

${ }^{*}$ ) This paper has been presented at the LT 15 Conference as a post deadline paper.

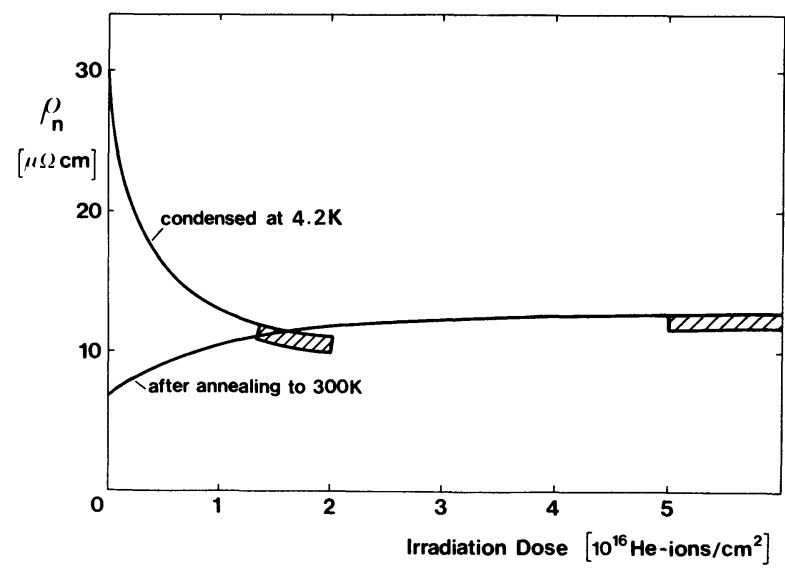

FIG. 1. - Residual resistivity $\rho_{n}$ of a Pd film condensed onto a substrate at $4.2 \mathrm{~K}$ versus dose of irradiating $\mathrm{He}^{+}$-ions before and after annealing at $300 \mathrm{~K}$. The hatched regions indicate the occurrence of superconductivity, with $T_{\text {cmax }}=2.5 \mathrm{~K}$ corresponding to the high ion beam density used in this special experiment.

of medium disorder between those obtained after evaporation at $4.2 \mathrm{~K}$ and $300 \mathrm{~K}$.

The occurrence of superconductivity in pure $\mathrm{Pd}$ is surprising because of its strongly enhanced paramagnetism. On the other hand there are some recent theories $[1,2]$ indicating the possibility of superconductivity in $\mathrm{Pd}$ at very low temperatures based on electron-phonon induced p-wave coupling. The occurrence of superconductivity in a disordered Pd phase, however, contradicts a p-wave mechanism in this phase. Possibly the defects lattice introduced suppress the harmful spin fluctuations, perhaps by Pd 
atoms occupying interstitial sites as a result of the irradiation. In this connection a very recent paper [3] should be mentioned predicting a $T_{\mathrm{c}}$ of $0.3 \mathrm{~K}$ for $\mathrm{Pd}$ without spin fluctuations and s-wave coupling. It seems more reasonable to assume s-wave coupling in the observed superconducting disordered Pd.

\section{References}

[1] Foulkes, I. F., Gyorffy, B. L., Phys. Rev. B 15 (1977) 1395.

[2] FAy, D., ApPel, J., Phys. Rev. B 16 (1977) 2325

[3] Pinski, F. J., Allen, P. B., Butler, W. H., Phys. Rev. Lett. 41 (1978) 431. 